\title{
Immunosuppressive Therapy and Hepatitis B Virus Reactivation
}

\author{
Immünsüpresif Tedavi ve Hepatit B Virüs Reaktivasyonu
}

\author{
Iftihar KÖKSAL
}

Karadeniz Technical University Faculty of Medicine, Department of Infectious Diseases, Trabzon, Turkey

\begin{abstract}
Reactivation of hepatitis B virus (HBV) refers to reappearance of active necroinflammatory disease of the liver in an individual at an inactive hepatitis B surface antigen carrier state or who is known to have resolved HBV infection. Patients receiving immunosuppressive therapy for malignant, autoimmune or chronic rheumatic diseases are at risk for $\mathrm{HBV}$ reactivation and a flare of their HBV infection due to loss of HBV immune control. HBV reactivation can be prevented by antiviral prophylaxis. Antiviral drugs given after the initiation of immunosuppressive therapy are less effective for liver injury and should not be preferred.

Keywords: Hepatitis B virus, immunosuppressive therapy, reactivation
\end{abstract}

OZZ

Hepatit B virüs (HBV) reaktivasyonu, inaktif hepatit B yüzey antijeni taşıyıcılarında veya iyileşmiş HBV enfeksiyonu olan kişilerde aktif nekroenflamatuvar karaciğer hastalığının yeniden ortaya çıkmasıdır. Malign, otoimmün ve romatizmal hastalıklarda kullanılan immünsupresif tedaviler, HBV immün baskılanmasının kaybına bağlı olarak HBV reaktivasyonu ve alevlenme için risk oluştururlar. HBV reaktivasyonu antiviral profilaksi ile önlenebilir. Immünsüpresif tedaviye başlandıktan sonra verilen antiviral ilaçlar karaciğer hasarını önlemek için daha az etkili olup tercih edilmemelidir.

Anahtar Kelimeler: Hepatit B virüs, immünsüpresif tedavi, reaktivasyon

Köksal İ. Immunosuppressive Therapy and Hepatitis B Virus Reactivation. Viral Hepat J. 2016;22:69-73.

\section{Introduction}

Hepatitis B virus (HBV) infection is a major public health problem worldwide and there are 350 million chronic HBV carriers in the world. On the other hand, approximately $30 \%$ of the world population shows serological evidence of current or past infection (1). HBV persists in the body of all patients with infection, even in those with evidence of serological recovery. These individuals when receiving immunosuppressive therapy for malignant, autoimmune, or chronic rheumatic diseases are at risk for HBV reactivation and a flare of their HBV infection due to loss of HBV immune control. This can result in increased serum aminotransferase levels, fulminant hepatic failure, and/or death. In addition, reactivation of HBV can lead to an interruption of immunosuppressive therapy, delaying treatment of the underlying disease (1).

\section{Reactivation Definition}

There is no consensus on the definition of HBV reactivation among guidelines. European Association for the Study of the Liver (EASL) and Asian Pacific Association for the Study of the Liver (APASL) chronic hepatitis B guidelines consider hepatitis B surface antigen ( $\mathrm{HBsAg}$ ) seroreversion and rise in HBV DNA levels as diagnostic criteria, whereas the American Association for the Study of Liver Diseases (AASLD) defines reactivation as reappearance of active necroinflammatory disease of the liver in an individual at an inactive HBsAg carrier state or who is known to have resolved hepatitis $B$.

Recently, a standardized nomenclature was made for the definition of HBV reactivation at the Reactivation of Hepatitis $B$ AASLD meeting held in 2013. Accordingly, reactivation of HBV replication was defined as a marked increase in HBV replication 
( $\geq 2$ log increase from baseline levels or a new appearance of HBV DNA to a level of $\geq 100 \mathrm{lU} / \mathrm{mL}$ ) in a person with previously stable or undetectable levels. The types of reactivation were described as reverse $\mathrm{HBsAg}$ seroconversion (reappearance of $\mathrm{HBsAg}$ ), or appearance of HBV DNA in serum in the absence of HBsAg. The severity of reactivation, defined by the presence or absence of jaundice and liver failure; and its outcome (return to baseline status or persistence in an activated state, need for liver transplantation or death) should also be reported $(2,3,4)$.

\section{Reactivation Mechanism and Reactivation Phases}

$\mathrm{HBV}$ reactivation is defined as a loss of HBV immune control in a patient with an inactive or a resolved HBV infection, resulting in a reappearance or increase in viral replication with liver damage occurring either during or following immune reconstitution. In the initial phase of reactivation, there is an increase in HBV DNA levels, usually with an asymptomatic evolution. In the second phase, both alanine aminotransferase (ALT) and HBV DNA are elevated; symptoms are frequently present and they may be severe and death may occur. In the third phase, resolution occur due to recovery of the immune system strength spontaneously or as a result of immunosuppressive therapy suspension or due to administration of antiviral drugs (Figure 1) (1).

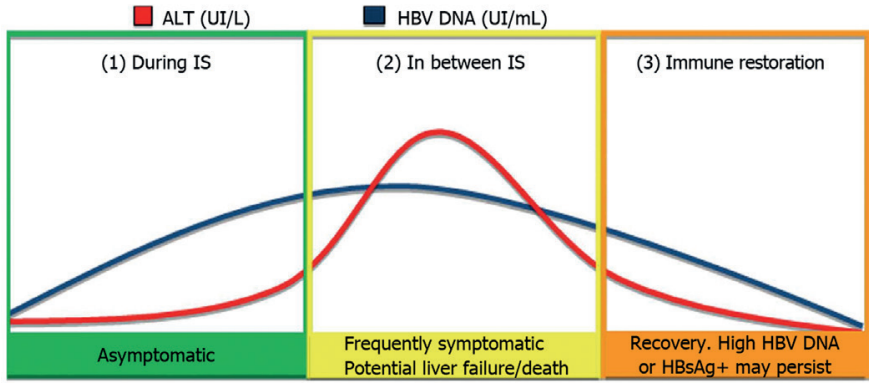

Figure 1. Hepatitis $B$ reactivation phases

IS: Immunosuppression, HBV: Hepatitis B virus, ALT: Alanine aminotransferase, HBsAg: Hepatitis B surface antigen (From Bessone $F$ et al. Hepatitis $B$ reactivation in immunosuppressed patients, World $J$ Hepatol. 2016;8:385-394)

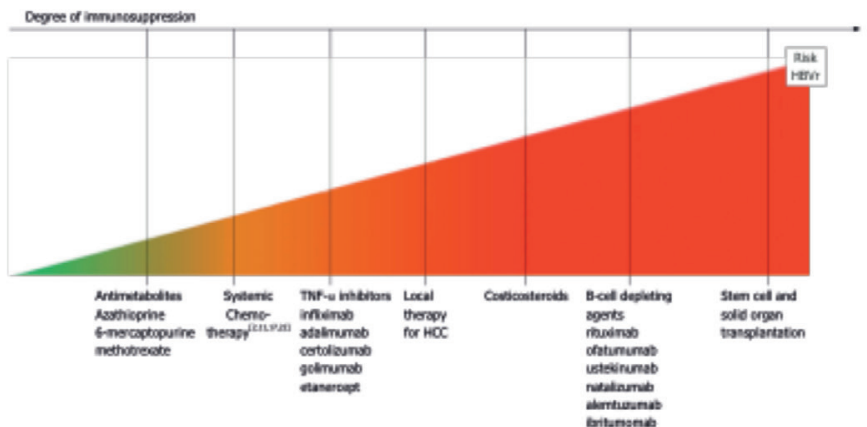

Figure 2. Immunosuppressing agents and related risk of hepatitis B reactivation

HCC: Hepatocellular carcinoma; TNF- $\alpha$ : Tumor necrosis factor- $\alpha$; HBVr: Hepatitis B virus reactivation (From Bessone F et al. Hepatitis $B$ reactivation in immunosuppressed patients, World J Hepatol. 2016:8:385-394)

\section{Risk Factors for Reactivation}

Patients with serologic evidence of HBV infection [HBsAgpositive or anti hepatitis B core antigen (anti-HBc)-positive] are at risk for $\mathrm{HBV}$ reactivation if they receive immunosuppressive therapy. Such patients include those being treated for malignancy or autoimmune and chronic rheumatic diseases.

HBsAg-positive patients are at greater risk for reactivation compared to HBsAg-negative patients. If HBsAg-positive patients have hepatitis $B$ e antigen ( $\mathrm{HBeAg}$ ) and/or high baseline levels of HBV DNA (HBV DNA level of $>104 \mathrm{lU} / \mathrm{mL}$ ), they have the highest risk of reactivation. HBsAg-negative, anti-HBc-positive patients have also reactivation risk if they receive immunosuppressive therapy. Reactivation can occur even in anti-HBs-positive patients. However, these patients have a lower risk of HBV reactivation (1).

\section{Reactivation-causing Medications}

HBV reactivation risk depends on some factors such as the power and duration of immunosuppression. Some medications, such as corticosteroids and rituximab containing chemotherapeutics, cancer chemotherapy for a variety of hematologic and solid tumors, intra-arterial chemoembolization for hepatocellular carcinoma, and anti-tumor necrosis factor (anti-TNF) therapies for inflammatory bowel disease, and rheumatoid arthritis have been held accountable for HBV reactivation (Figure 2) $(1,5,6)$.

\section{Corticosteroids}

In HBsAg-positive patients, HBV reactivation risk increases with corticosteroid therapy with high-dose, rapidly tapered regimens and moderate-dose, prolonged regimens. Reactivation is very rare with low-dose regimens (i.e., <20 mg prednisone per day), even over prolonged periods. Despite the increase in viral replication, serum aminotransferases tend to decline. The opposite occurs once corticosteroids are withdrawn; viral replication decreases while aminotransferases increase. The peak rise in aminotransferase levels typically occurs four to six weeks after withdrawal. HBV reactivation risk increases when corticosteroids are given with other chemotherapy agents.

\section{Chemotherapeutic Agents}

HBV reactivation risk is very high among HBsAg-positive patients receiving chemotherapy with a rate of $70 \%$. Reactivation rates are different according to chemotherapeutic agents, their doses and duration. The risk is higher with the use of regimens that include anti-CD20 monoclonal antibodies and/or glucocorticoids (Figure 2).

\section{Drugs for Autoimmune Disorders}

Recent studies describe HBV reactivation and flares of hepatitis among patients with autoimmune disorders being treated with a variety of immunosuppressive agents. Anti-TNFs are important drugs for HBV reactivation. In addition to TNF inhibitors, other immunosuppressive drugs, such as methotrexate, abatacept and ustekinumab, may cause HBV reactivation. 
Table 1. Recommendations for antiviral prophylaxis in patients receiving cytotoxic or immunosuppressive therapy

\begin{tabular}{lll}
\hline AASLD AGA EASL & AGA
\end{tabular}

Antiviral prophylaxis

recommended for HBV carriers at

the start of cancer chemotherapy

or of a finite course of

immunosuppressive therapy in the

following patients:

Baseline HBV DNA < $2.000 \mathrm{IU} /$

$\mathrm{mL}$ level and should continue

treatment for 6 months after

completion of chemotherapy or

immunosuppressive therapy

Baseline HBV DNA (>2.000 IU $/ \mathrm{mL})$

level and should continue treatment

until they reach treatment endpoints

as in immunocompetent patients

Lamivudine or telbivudine can be used if the anticipated duration of treatment is short ( $<12$ months) and baseline serum HBV DNA not detectable.

Tenofovir or entecavir is preferred if longer duration of treatment is anticipated.

Interferon should be avoided
Antiviral prophylaxis is recommended for patients with high risk for reactivation:

$\mathrm{HBsAg}+/$ anti-HBc+ or HBsAg-/anti-HBc+ treated with $B$ cell-depleting agents (e.g., rituximab, ofatumumab)

$\mathrm{HBsAg}+/ \mathrm{anti}-\mathrm{HBc}+$ patients treated with either: Anthracycline derivatives (e.g., doxorubicin, epirubicin)

Moderate- or high-dose corticosteroids daily for $\geq 4$ weeks

Antiviral prophylaxis over monitoring is suggested for patients with moderate risk for reactivation: $\mathrm{HBsAg}+/ \mathrm{anti}-\mathrm{HBc}+$ or $\mathrm{HBsAg}$-/anti-HBc+ patients treated with:

TNF inhibitors (e.g., etanercept, adalimumab, certolizumab, infliximab)

Cytokine or integrin inhibitors (e.g., abatacept, ustekinumab, natalizumab, vedolizumab) TKIs (e.g., imatinib, nilotinib)

$\mathrm{HBsAg}+/$ anti-HBc+ patients treated with low-dose corticosteroids for

$\geq 4$ weeks

HBsAg-/anti-HBc+ patients treated with either:

Moderate- or high-dose corticosteroids for

$\geq 4$ weeks

Anthracycline derivatives (e.g., doxorubicin, epirubicin)

Antiviral prophylaxis is not recommended for patients with low risk for reactivation:

$\mathrm{HBsAg}+/ \mathrm{anti}-\mathrm{HBc}+$ or $\mathrm{HBsAg}$-/anti-HBc+ patients treated with:

Traditional immunosuppressive agents (e.g., azathioprine, mercaptopurine, methotrexate) Intra-articular corticosteroids.

Any dose of oral corticosteroids for

$\leq 1$ week

$\mathrm{HBsAg}$-/anti-HBc+ patients treated with low-dose

corticosteroids for

$\geq 4$ weeks

Antivirals with a high barrier to resistance are

preferred over lamivudine

Antivirals should be continued for $\geq 6$ months after immunosuppressive therapy discontinuation
HBsAg+ candidates for chemotherapy and immunosuppressive therapy should receive preemptive NA administration during therapy (regardless of HBV DNA levels) for 12 months after cessation of therapy

Patients with high HBV DNA level and/ or who may receive a lengthy course of immunosuppression, should receive an NA with high antiviral potency and a high barrier to resistance such as entecavir or tenofovir

Some experts recommend prophylaxis with amivudine in all $\mathrm{HBsAg}$-/anti-HBc+ patients receiving rituximab and/or combined regimens for hematologic malignancies, if they are anti-HBs- and/ or if close monitoring of HBV DNA is not guaranteed

NA prophylaxis is recommended for anti$\mathrm{HBc}+$ patients receiving bone marrow or stem cell transplantation; the optimal duration of prophylaxis for these indications is not known

HBsAg- recipients of liver grafts from anti$\mathrm{HBc}+$ donors should receive prophylaxis with lamivudine and should be continued indefinitely

HBV: Hepatitis B virus, HBsAg: Hepatitis B surface antigen, TNF: Tumor necrosis factor, TKI: Tyrosine kinase inhibitor, AASLD: American Association for the Study of Liver Diseases, AGA: American Gastroenterological Association, EASL: European Association for the Study of the Liver

\section{Anti-tumor Necrosis Factor Agents and Therapeutic Monoclonal Antibodies}

TNF inhibitors have been found to be associated with HBV reactivation. TNF inhibitors are used for the treatment of Crohn disease and other intestinal inflammatory disorders, rheumatic diseases, and psoriasis. Among HBsAg-positive patients, the frequency of $\mathrm{HBV}$ reactivation has ranged from 0 to 40 percent.
The use of concurrent or prior immunosuppressive therapy may contribute to the risk of reactivation. Newer agents, such as therapeutic monoclonal antibodies (rituximab, ofatumumab, and alemtuzumab), may also precipitate HBV reactivation. The US Food and Drug Administration approved the addition of a boxed warning to the prescribing information of rituximab and ofatumumab about this risk and recommends that healthcare professionals: 
- Measure HBsAg and anti-HBc levels to determine if a patient is infected with HBV before beginning therapy with rituximab or ofatumumab.

- If screening identifies patients at risk of HBV reactivation due to evidence of previous HBV infection, consult with hepatitis experts prior to use of these agents.

- If treating patients with evidence of previous HBV infection with rituximab or ofatumumab, monitor for clinical and laboratory signs of hepatitis B or HBV reactivation during therapy and for several months thereafter.

- Immediately discontinue rituximab or ofatumumab in patients who develop reactivation of HBV while on therapy and start appropriate treatment for $\mathrm{HBV}$; in addition, any chemotherapy the patient is receiving should be discontinued until the HBV infection is controlled or resolved.

Briefly, all patients receiving anti-TNF agents and therapeutic monoclonal antibodies therapy should be screened for HBV serologic profile.

Serologic tests should include anti-HBc and HBsAg. If there is serological evidence of HBV infection, baseline HBV DNA levels should be measured. Anti-HBs test is not routine because the role of anti-HBs on HBV reactivation is not well known.

\section{Diagnosis and Monitoring of Hepatitis B Virus Reactivation}

There is no consensus among guidelines on screening and monitoring recommendations. The consensus guidelines from the AASLD (Management Guidelines), EASL (Management Guidelines), (EASL HBV) and the Centers for Disease Control and Prevention (Management Guidelines) recommend screening for hepatitis B prior to initiating immunosuppressive therapies. The American Gastroenterological Association (AGA), however, recommends screening for HBV only in patients with moderate or high risk for HBV who will receive immunosuppressive therapy and suggests against routine screening in patients at low risk citing cost-effectiveness and false-positive rates as reasons for not screening $(2,4,7)$. If the patient is HBsAg-positive, should be tested for $\mathrm{HBeAg}$ and anti-HBe, in addition to HBV DNA levels. If the patient is HBsAg-negative but anti-HBc-positive, hepatitis $B$ reactivation can still occur and close monitoring of HBV DNA and ALT levels during immunosuppressive therapy is warranted. The risks associated with this reactivation can be great and fatal HBV flares in anti-HBc-positive patients who received rituximab-containing chemotherapy for lymphoma. The patients should also be tested for other concurrent infections, such as hepatitis D virus, hepatitis C virus, and HIV. Then, the patients with serologic evidence of HBV infection should be considered for the severity of reactivation risk. Some patients with HBV reactivation are asymptomatic and have normal liver chemistries. Some patients can have a flare of their HBV infection with increased aminotransferase levels and signs and symptoms of liver disease. Patients with detectable HBV DNA should be treated in similar way to HBeAg-positive patients. For patients with undetectable HBV DNA, HBV DNA and ALT should be monitored frequently, every 1-3 months depending on the type of immunosuppressive therapy and comorbidities. In addition, the EASL recommends vaccination of HBV-seronegative patients and notes that higher vaccine doses may be needed in immunocompromised patients.

\section{Level of Reactivation Risk}

Very high risk: Patients are at very high risk of reactivation (>20 percent risk of reactivation) if they are HBsAg-positive and are going to receive therapeutic monoclonal antibodies (i.e. rituximab, ofatumumab, obinutuzumab) or undergo hematopoietic cell transplantation. Particularly rituximab is considered an important risk factor for HBV reactivation.

High risk: Patients are considered at high risk for reactivation (11 to 20 percent risk of reactivation) if they are HBsAg-positive and are going to receive high-dose corticosteroids (e.g., $\geq 20 \mathrm{mg} /$ day for at least four weeks) or therapeutic monoclonal antibodies, alemtuzumab.

Moderate risk: $\mathrm{HBsAg-positive} \mathrm{patients} \mathrm{are} \mathrm{at} \mathrm{moderate} \mathrm{risk} \mathrm{of}$ reactivation (1 to 10 percent) if they are going to receive cytotoxic chemotherapy without corticosteroids; anti-TNF therapy; or antirejection therapy for solid organ transplants.

Patients who are HBsAg-negative and anti-HBc-positive are at moderate risk for reactivation if they are going to receive therapeutic monoclonal antibodies therapy or undergo hematopoietic cell transplantation.

Low risk: HBsAg-positive patients are at low risk ( $<1$ percent) for reactivation if they receive methotrexate or azathioprine. $\mathrm{HBsAg-negative} \mathrm{and} \mathrm{anti-HBc-positive} \mathrm{individuals} \mathrm{are} \mathrm{at} \mathrm{low} \mathrm{risk}$ if they receive high-dose corticosteroids (e.g., $\geq 20 \mathrm{mg} /$ day) or the therapeutic monoclonal antibody, alemtuzumab.

Very low risk: $\mathrm{HBV}$ reactivation occurs rarely in $\mathrm{HBsAg-negative}$ and anti-HBc-positive patients receiving cytotoxic chemotherapy without corticosteroids; anti-TNF therapy; anti-rejection therapy for solid organ transplants; methotrexate; or azathioprine.

\section{Clinical Findings of Reactivation}

Most patients with HBV reactivation are asymptomatic, and there is an increase only in the HBV DNA level. Some patients have increased aminotransferase levels with or without clinical signs and symptoms such as nausea and vomiting. Severe flares can be associated with jaundice, hepatic decompensation, and death; poor outcomes are more likely to occur in cirrhotic patients.

\section{Hepatitis B Virus Prophylaxis}

All patients who develop HBV reactivation should be treated. Current guidelines, the AASLD, EASL, and AGA, recommend preemptive or prophylactic therapy before starting chemotherapy or immunosuppressive therapy. Antiviral drugs given after the initiation of immunosuppressive therapy are less effective for liver injury and should not be preferred. The recommendations of the guidelines for prophylaxis are summarized in Table $1(2,4,7)$. 
Patients with HBV reactivation (with or without a flare) should be treated with entecavir or tenofovir. The duration of treatment depends on the duration and the type of immunosuppressive therapy, the HBV DNA level, and the degree of underlying liver disease.

Tenofovir or entecavir should be chosen for treatment. The decision about which agent to use is based, in part, upon renal function. In patients with reduced kidney function, tenofovir should be avoided. Lamivudine should be given only in short-term course of immunosuppressive treatment since patients receiving lamivudine are at increased risk of developing drug-resistant virus infection. Tenofovir should be preferred for patients who received prior lamivudine therapy. If antiviral therapy is not started, these patients must be monitored closely.

There are no data to guide how long antiviral therapy should be administered before initiating immunosuppressive therapy. Treatment prophylaxis refers to antiviral therapy started before or concurrently as the initiation of immunosuppressive therapy, and before a rise in aminotransferase or HBV DNA levels occurs. However, in patients with a high baseline serum HBV DNA level (e.g., >4 log10 international units/mL), immunosuppressive therapy should be deferred until the HBV DNA level is suppressed to $<3$ $\log 10$ international units/mL.

\section{Duration of Therapy}

Although there is no consensus regarding the duration of treatment, the duration of therapy for treatment and prevention is the same and treatment should be maintained for at least 6 months after withdrawal of immunosuppression (AASLD and APASL societies suggest). However, according to the EASL, the recommended duration is 12 months. Treatment should be maintained for at least 12 months after cessation of rituximab $(2,3,4)$.
Antiviral therapy should be continued long-term for hematopoietic stem cell or solid organ transplantation patients since they often remain on chronic immunosuppressive treatment.

\section{Conclusion}

Before starting immunosuppressive therapy, the patients should be screened for HBV. All patients who are serologically HBV infection-positive and will receive immunosuppressive treatment should be evaluated for reactivation risk, and prophylaxis should be planned according to the risk factors.

\section{Ethics}

Peer-review: External and Internal peer-reviewed.

\section{References}

1. Bessone F, Dirchwolf $\mathrm{M}$. Management of hepatitis B reactivation in immunosuppressed patients: An update on current recommendations. World J Hepatol. 2016;8:385-394.

2. Lok ASF, Bonis PAL. Hepatitis B virus reactivation associated with immunosuppressive therapy. UpToDate. 2016.

3. Zeuzem S. Patients at Risk for Hepatitis B Virus Reactivation. Hepatitis B Management in Special Populations. InPractice. 2016.

4. Reddy KR, Beavers KL, Hammond SP, Lim JK, Falck-Ytter YT; American Gastroenterological Association Institute. American Gastroenterological Association Institute guideline on the prevention and treatment of hepatitis $B$ virus reactivation during immunosuppressive drug therapy. Gastroenterology. 2015;148:215-219.

5. Terrault NA, Bzowej NH, Chang KM, Hwang JP, Jonas MM, Murad $\mathrm{MH}$; American Association for the Study of Liver Diseases. AASLD Guidelines for Treatment of Chronic Hepatitis B. Hepatology. 2016;63:261-283

6. Lok AS, McMahon BJ. Chronic hepatitis B. Hepatology 2009;50:661-662.

7. EASL clinical practice guidelines: Management of chronic hepatitis B virus infection. J Hepatol. 2012;57:167-185. 